\title{
Oil spill fate forecast system for Ilha Grande Bay, Rio de Janeiro, Brasil
}

\author{
M. da R. Fragoso ${ }^{1}$, A. R. Torres $\mathrm{Jr}^{1}$, N. Mehdi ${ }^{1}$, G. B. França ${ }^{1}, \&$ J. \\ A. M. Lima ${ }^{2}$ \\ ${ }^{\prime} C O P P E-I G E O-F e d e r a l$ University of Rio de Janeiro, Brasil \\ ${ }^{2}$ Cenpes - Petrobras Research Center
}

\begin{abstract}
Baia da Ilha Grande is a bay located south Rio de Janeiro city, Brazil. It is a very important water body in regard to economic and ecological purposes, since it has a major commercial harbor, an oil terminal, many industries and two nuclear power plants. It is also one of the most important tourist resorts of Rio. An applied research study was made by the Marine and Atmospheric Processes Modeling Laboratory (LAMMA) of Universidade Federal do Rio de Janeiro to the Brazilian state oil company Petrobras in order to evaluate the hydrodynamic circulation in the bay and fate of oil spills that could take place in the Petrobras oil terminal. It was used the 3-D baroclinic oceanic numerical model Princeton Ocean Model (POM) to simulate the current field using both tidal and wind forcing. The oil spill model Nicoil developed by LAMMA that considers the most important weathering processes was implemented in this region. Methods and results are presented.
\end{abstract}

\section{Introduction}

The Ilha Grande bay is part of a complex estuarine system situated in the south shore of Rio de Janeiro State (between the latitudes $22^{\circ} 55^{\prime} \mathrm{S}$ e $23^{\circ} 25^{\prime} \mathrm{S}$ and the longitudes $44^{\circ} 42^{\prime} \mathrm{W}$ e $43^{\circ} 34^{\prime} \mathrm{W}$ ) with an area of approximately $3100 \mathrm{Km}^{2}$. The 
bay is separated in two water bodies by a channel between the Grande Island and the continent (Figure 1).
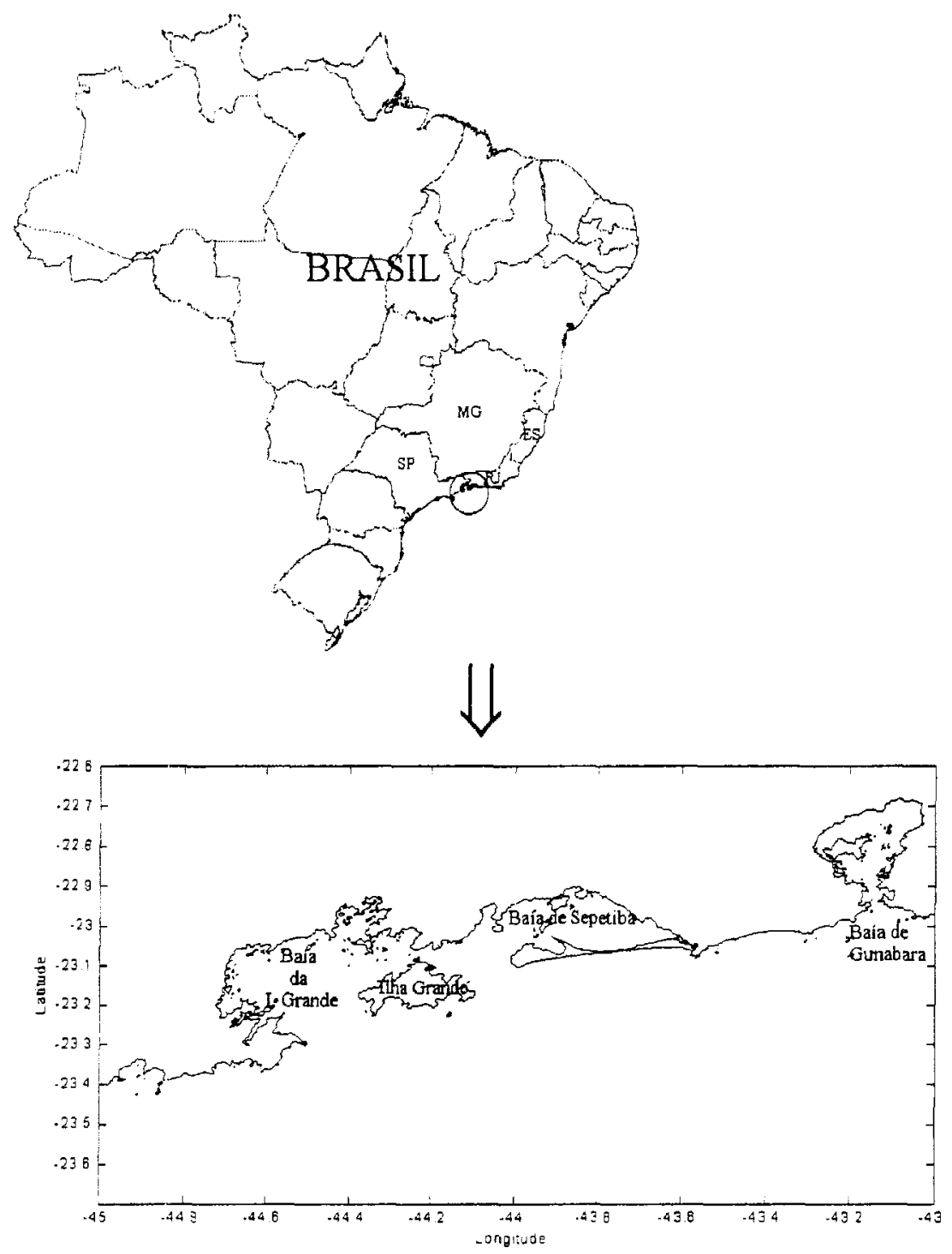

Figure 1: The Rio de Janeiro State south shore showing Guanabara Bay, Ilha Grande Bay and Grande Island.

Inside Ilha Grande bay is located a Petrobras oil terminal (GEBIG), two nuclear power plants and one of the major harbors of Brasil, as well as many other 
industries. All that situated in a region that has environmentally protected areas and important tourist resorts.

This paper describes the Ilha Grande Oil Spill Forecast System that was elaborated by the Marine and Atmospheric Processes Modeling Laboratory of Federal University of Rio de Janeiro and has been used by the Brazilian state oil company Petrobras.

\section{Objective}

The objective of the Oil Spill Fate Forecast System for Ilha Grande Bay is to be an operational tool to prevent possible environmental damage due to any Petrobras' Ilha Grande Oil Terminal (GEBIG) accidental oil spill.

\section{Methodology}

The Ilha Grande Oil Spill Forecast System consists of two subsystems: the hydrodynamic model that is used to predict the currents in Iha Grande Bay and the Oil Spill Model that uses the current data generated by the hydrodynamic model in order to predict the fate of the oil spill.

\subsection{Description of hydrodynamic model}

In order to obtain the marine current field of Ilha Grande bay, the Princeton Ocean Model (POM) was applied for this region. This model, described in Blumberg and Mellor (1983), was initially developed to be used in both bays and oceanic regions, and has been successfully applied in the study of many complex bays, such as Chesapeake Bay and others. It has many users worldwide and has been tested over diverse applications.

The model uses vertical sigma coordinate system, and solves the primitive equations, using both hydrostatic and Boussisnesq approximations. It also uses a time splitting technique that solves barotropic and baroclinic variables with different time steps in order to reduce processing time. It was used 17670 horizontal grid points covering the whole Ilha Grande bay, the x-direction was discretized with 114 grid points along the $\mathrm{E}-\mathrm{W}$ direction and the $\mathrm{y}$-direction with 155 grid points along the N-S direction in a orthoghonal rectilinear telescopic grid with variable spatial resolution in range that goes from $926 \mathrm{~m} \mathrm{X} 387 \mathrm{~m}$ to $18.000 \mathrm{~m} \times 20.000 \mathrm{~m}$. It was used 6 sigma layers for the experiments with baroclinic mode.

The Ilha Grande bay model has three open boundaries; east, south and west and a specific set of boundary conditions had to be implemented for the prognostic variables: tidal forcing is prescribed as an elevation boundary condition, zero gradient condition is used for normal barotropic velocities, an upstream advection condition is applied to tangential barotropic velocities, wave radiative 
condition is applied to baroclinic velocities and upstream advection condition is applied to temperature and salinity.

The tidal elevation at the boundary was calculated taking into account the seven main tidal harmonic components for the site (M2,S2,N2,K2,K1,O1 e Q1). The wind forcing is prescribed as a surface stress component in the momentum equations and it was considered a mean barotropic temperature and salinity profile for the initial conditions.

\subsection{Description of oil spill model}

The oil spill model was developed as a numerical tool to study the behavior and approximate trajectory of oil spills in water bodies. It is a two-dimensional model that simulates the sea surface fate of oil spills solving the equation for advection and diffusion of passive constituents. It is included typical processes associated with oil fate in water: evaporation, spreading and entrainment. The oil dispersion is modelled in terms of the thickness of the oil layer at a specific grid point.

The governing equation of the oil spill model is as follows:

$$
\frac{d \varphi}{d t}=\frac{\partial \varphi}{\partial t}+u \frac{\partial \varphi}{\partial x}+\nu \frac{\partial \varphi}{\partial y}=\kappa\left(\frac{\partial^{2} \varphi}{\partial x^{2}}+\frac{\partial^{2} \varphi}{\partial y^{2}}\right)+S p r+E v a p+E n t r
$$

Where $\varphi$ is the ratio oil thickness/water depth, Spr is the spreading term, Evap is evaporation term, and Entr is entrainment term. The above equation is solved using a finite difference techinique with an Euler forward scheme for time and quadratic upstream interpolation for convective kinematics with estimated stream term (QUICKEST) scheme for space.

To solve the oil spreading at the sea surface, it is used the formulation proposed by Fay (1972) and Hoult (1972) as modified by Mackay et al (1980). The rate of variation of the area of oil spill is expressed by:

$$
\mathrm{dA} / \mathrm{dt}=\mathrm{K} 1 \mathrm{~A} 0.3(\mathrm{Vm} / \mathrm{A})^{1.3}
$$

where $\mathrm{A}=$ spill area $\left(\mathrm{m}^{2}\right) ; \mathrm{Kl}=$ spreading rate constant $\left(\mathrm{s}^{-1}\right)$ with $\mathrm{K} 1=5 \times 108 /$ day from (Audunson et al,1984 apud Reed, 1989) and $\mathrm{Vm}=$ spill volume $\left(\mathrm{m}^{3}\right)$. From this equation, it is assumed that time evolution of oil thickness is defined by $\mathrm{h}=\mathrm{Vm} / \mathrm{Ai}$, where index i represents time.

The evaporation process is usually the most important one associated with the reduction of oil mass in any spill. This process is influenced by the chemical composition of the oil, air and water temperature, spill area, wind speed, sun 
radiation and oil layer thickness. It is used the formulation proposed by Mackay \& Matsugu (1973) to express the rate of mass reduction $\mathrm{dM} / \mathrm{dt}$ :

$$
\frac{\mathrm{dM}}{\mathrm{dt}}:=\mathrm{K} \cdot \mathrm{P} \cdot \mathrm{Pvp} \cdot \frac{\mathrm{A}}{\mathrm{R} \cdot \mathrm{T}} \cdot \mathrm{f} \cdot \mathrm{Mw}
$$

with the variable $\mathrm{K} 2$ parameterized as:

$$
\mathrm{K} 2_{\mathrm{i}}:=0.029 \cdot \mathrm{W}^{.78} \cdot\left(\mathrm{D}_{\mathrm{i}}\right)^{-.11} \cdot \mathrm{Sc}^{-.67} \cdot \sqrt{\frac{\mathrm{Mw}+29}{\mathrm{Mw}}}
$$

where $\mathrm{W}=$ wind speed $(\mathrm{m} / \mathrm{h}) ; \mathrm{D}=$ oil spill diameter $(\mathrm{m}) ; \mathrm{Sc}=\mathrm{Schmidt}$ number (2.7); $\mathrm{Mw}=$ molecular weight $(\mathrm{g} / \mathrm{mol})$ of volatile components; Pvp = vapor pressure $(\mathrm{atm}) ; \mathrm{R}=$ universal gas constant; $\mathrm{T}=$ temperature $(\mathrm{K})$ and $\mathrm{F}=$ ratio of volatile components. Thus, the amount of evaporated oil $\mathrm{Mi}\left(\mathrm{m}^{3}\right)$ can be expressed into the oil layer thickness by $\mathrm{h}=\mathrm{Mi} * 10-6 / \mathrm{Ai}$.

The entrainment process of surface oil spill into the water column can be expressed by formulation proposed by Mackay et al (1980 apud Reed, 1989):

$$
\begin{gathered}
\mathrm{Da}:=0.11 \cdot(\mathrm{W}+1)^{2} \\
\mathrm{Dh}_{\mathrm{i}}:=\left(1+50 \cdot \mu^{0.5} \cdot \mathrm{h}_{\mathrm{i}} \cdot \mathrm{St}\right)
\end{gathered}
$$

where $\mathrm{Da}=$ fraction of surface oil subjected to entrainment; $\mathrm{W}=$ wind speed $(\mathrm{m} / \mathrm{s}) ; \mathrm{Dhi}=$ fraction of oil that does not return to the spill; $\mu=$ oil viscosity $(\mathrm{g} / \mathrm{m} \mathrm{s}) ; \mathrm{hi}=$ oil layer thickness $(\mathrm{m})$ and $\mathrm{St}=$ oil-water interface tension. The oil viscosity varies as mousse builds up (Mackay et al, 1980 apud Reed, 1989) and can be modeled as:

$$
\mu_{i}:=\mu 0 \cdot e^{C 4 \frac{M 2_{i}}{V m}}
$$

where $\mu 0=$ initial viscosity; $\mathrm{C} 4$-varies froml (gasoline) to 10 (other petroleum products); $\mathrm{M} 2$ = evaporated mass and $\mathrm{Vm}=$ initial mass.

The ratio between $\mathrm{M} 2$ and $\mathrm{Vm}$ represents the evaporated fraction. The amount of entrainned oil $\mathrm{Ei}$ (cubic meters) is given by:

$$
E_{i}:=D a \cdot\left[1+50\left(\mu_{i}\right)^{\cdot 5} \cdot h_{i} \cdot S t\right]^{-1}
$$

The amount of entrainned oil is expressed as oil layer thickness by hi $=\mathrm{Ei} / \mathrm{Ai}$ 


\section{Results}

\subsection{Hydrodynamic model calibration}

In order to evaluate the results of the hydrodynamic model, two simulations were performed. The model was integrated for 10 days in its barotropic (2D) and baroclinic (3D) modes using only tidal elevation data as boundary as forcing. Comparisons between the model results in both simulations and tidal predictions for a harbour inside Ilha Grande bay were performed. The results (Figure 2) showed that the model was able to reproduce satisfactory the tides in the Ilha Grande bay region both in its $2 \mathrm{D}$ and $3 \mathrm{D}$ modes.

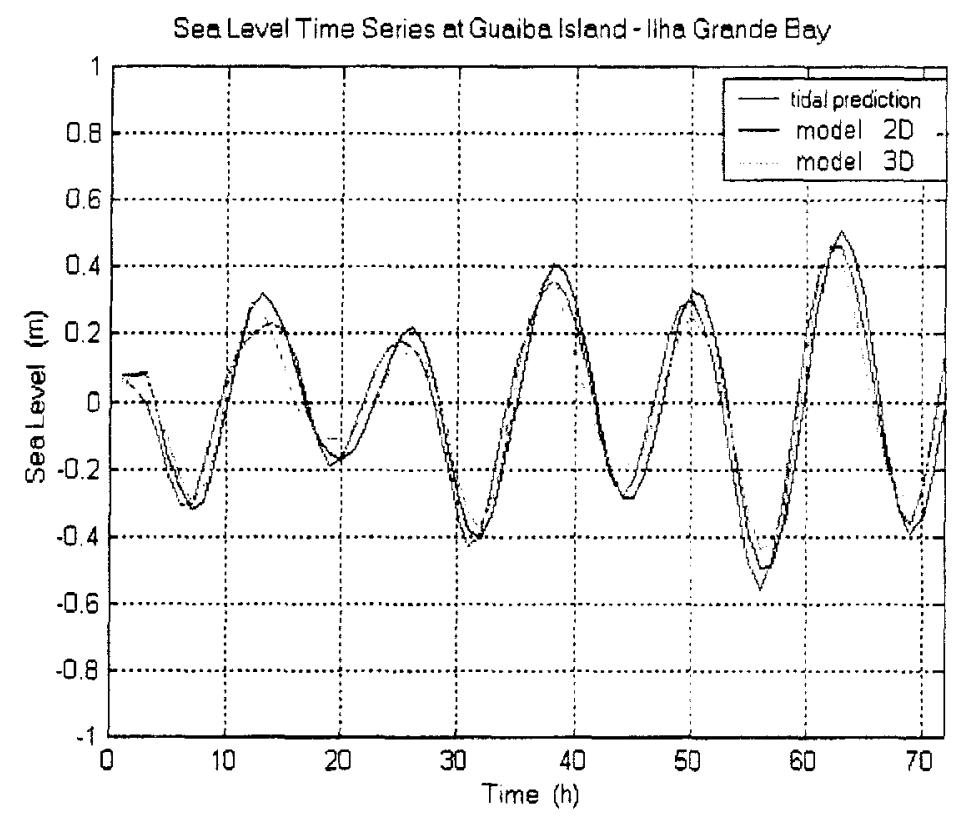

Figure 2: Comparison of sea level time series between model results and tidal prediction at Ilha Grande bay.

\subsection{Oil spill model calibration}

In order to evaluate the oil spill results in Ilha Grande bay, an oil spill hindcast was performed and compared with oil spill data that took place in the Petrobrs oil terminal (GEBIG) inside Iha Grande bay. A ship docked in the harbour spilled approximately 4000 litre of crude oil in the bay. The characteristics of the simulation are outlined in Table I. 


\section{Table I-Characteristics of the Oil Spill Simulation}

\begin{tabular}{|l|l|}
\hline Location: & Gebig harbor \\
\hline Volume of spill: & 4000 litre \\
\hline Wind speed and direction: & $5 \mathrm{~m} / \mathrm{s}$ - Southwest \\
\hline Kind of oil: & Crude \\
\hline API: & 27.9 \\
\hline Volatile oil fraction: & 0.40 \\
\hline
\end{tabular}

The hydrodynamic model was run with tides and wind forcing data of that date (Figure 3).

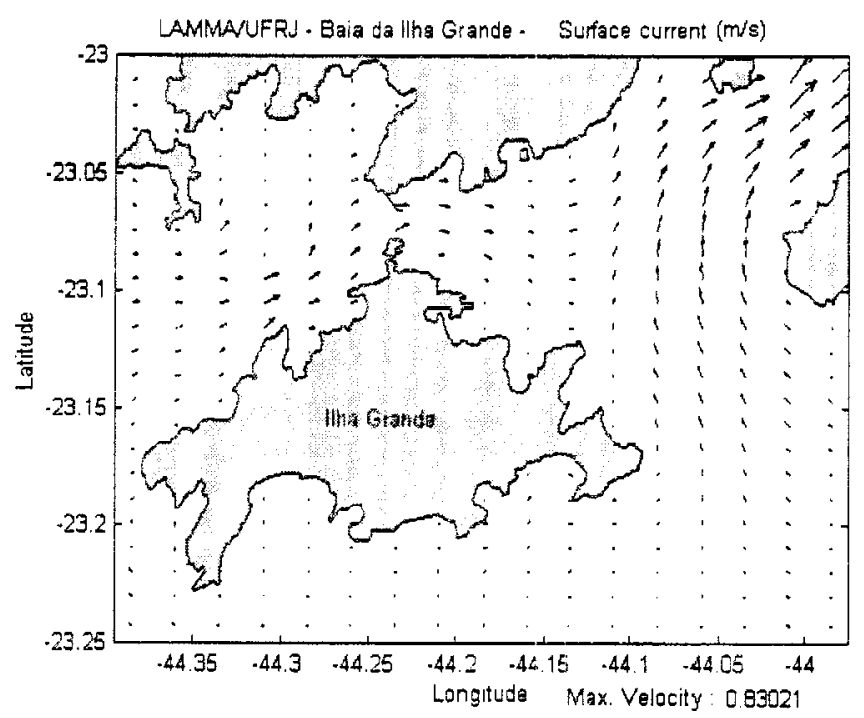

Figure 3: Example of the current field of Ilha Grande bay obtained by the hydrodynamic model.

The current data was than used by the oil spill model to hindcast the oil fate. The results were compared with observational data from visual inspection.

The visual inspection realized by Petrobras technicians showed that $24 \mathrm{~h}$ after the spill the oil reached Itapinhoacanga beach and thin oil slick was found in the channel between Grande Island and the continent. The model results show very similar pattern (Figure 5). 


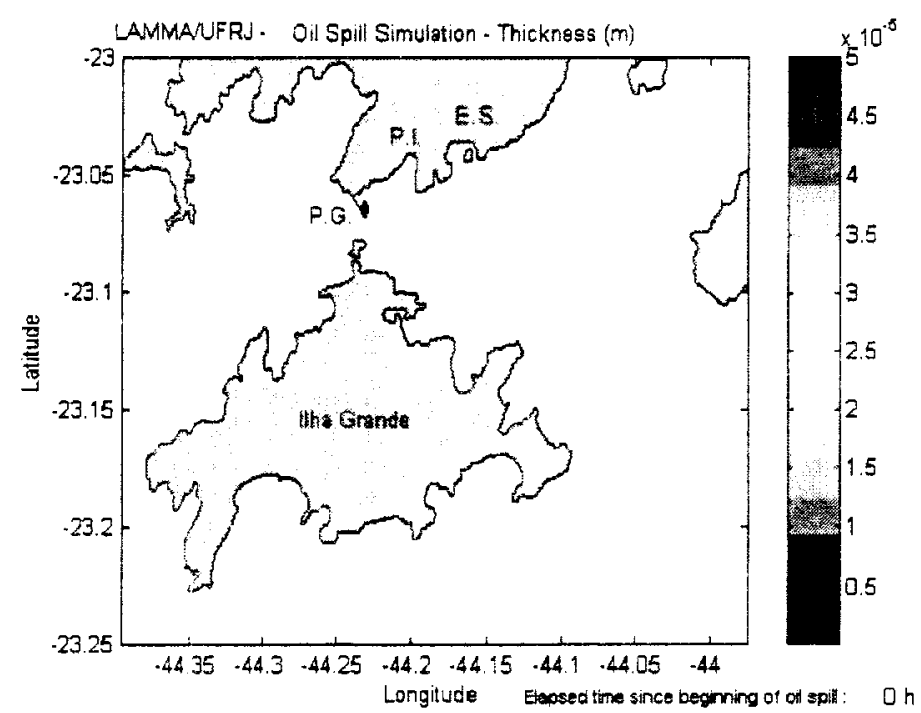

Figure 4: Initial conditions of the oil spill model - P. G. = Gebig Harbor P.I. = Itapinhoacanga beach. E.S. = Enseada da Sororoca.

Forty hours after the spill the oil was found in thin slicks between Itapinhoacanga beach and Enseada da Sororoca. The model results were also very similar to the description (Figure 6).

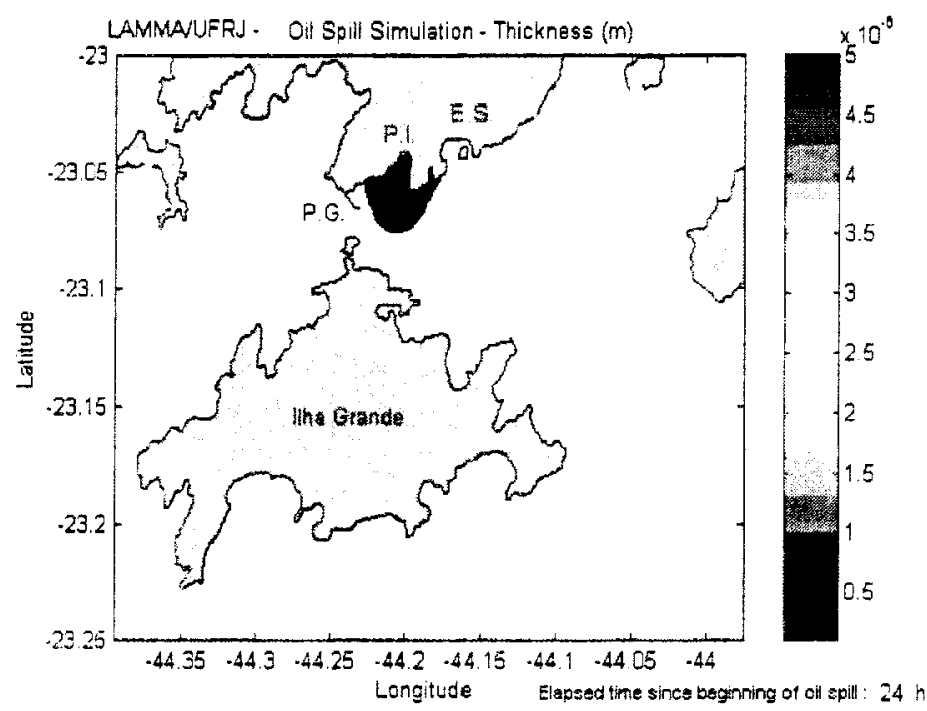

Figure 5: 24-hour snapshot of the oil spill model - P. G. = Gebig Harbor P.I. = Itapinhoacanga beach. E.S. $=$ Enseada da Sororoca. 


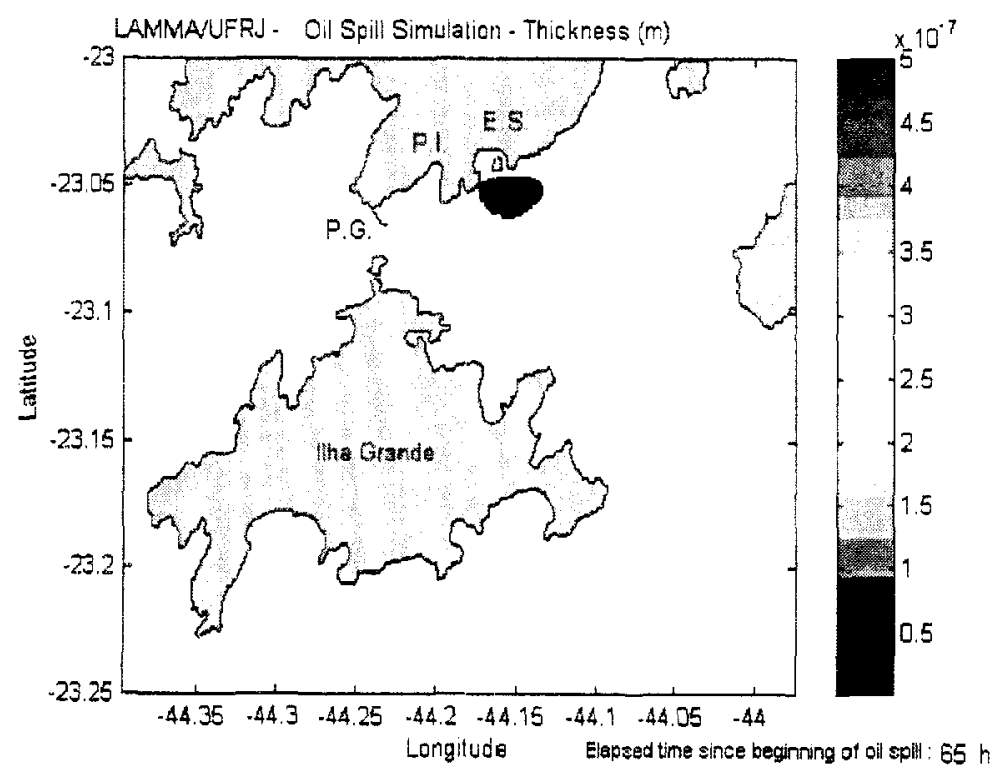

Figure 6: 65-hour snapshot of the oil spill model - P. G. = Gebig Harbor P.I. $=$ Itapinhoacanga beach. E.S. = Enseada da Sororoca.

\section{Concluding remarks}

An Oil Spill Fate Forecast System for Ilha Grande Bay developed by Marine and Atmospheric Processes Modeling Laboratory (LAMMA) of Federal University of Rio de Janeiro (UFRJ) was implemented operationally at Petrobras oil company.

A hydrodynamic model was calibrated for Ilha Grande Bay region and presented good results when compared to measured data.

An oil spill dispersion model was set up for Ilha Grande Bay region and showed satisfactory results compared to data from visual inspection.

The Oil Spill Fate Forecast System for Ilha Grande Bay can be used as a valuable tool for preveting any possible environmental damage caused by accidental oil spills in the Petrobras oil. terminal at Ilha Grande Bay.

\section{Acknowledgments}

The author would like to thank the Brazilian National Petroleum Agency (ANP) for the financial support of his $\mathrm{PhD}$ scholarship. 


\section{References}

Blumberg, A.F. \& G.L. Mellor.1983.: Diagnostic and prognostic numerical circulation studies of the South Atlantic Bight. J. Geophys. Res., 83, 873883.

Fay, J. A., 1971.: Physical processes in the spread of oil on a water surface. Proceedings of the Joint conference on Prevention and Control of Oil Spills. American Petroleum Institute, pp 463-7.

Hoult, D. P., 1972.: Oil spreading on the Sea. Ann. Rev. Fluid Mech., ed M. Van Dyke. W. Vincenti \& J. Wehausen. Annual Reviews. Inc. Palo Alto, CA. pp 341-68.

Mackay, D. \& R. S. Matsugu, 1973.: Evaporation rates of liquid hydrocarbon spills on land and water. Can J. Chem. Eng., 51. 434-9.

Mackay, D. et al, 1980.: Oil Spill Processes and Models. Environmental Impact Control Directorate., 95pp.

Reed, M., 1989.: The Physical Fates Component of The Natural Resource Damage Assessment Model System. Oil \& Chemical Pollution. Elesevier Science Publishers Ltd. England. 